\title{
An Outbreak of Acute Hepatitis Caused by Genotype IB Hepatitis A Viruses Contaminating the Water Supply in Thailand
}

\author{
Kriangsak Ruchusatsawat ${ }^{\mathrm{a}} \quad$ Jongkonnee Wongpiyabovorn ${ }^{\mathrm{c}}$ \\ Chonthicha Kawidam $^{a}$ Laddawan Thiemsing ${ }^{a}$ Somchai Sangkitporn ${ }^{a}$ \\ Sayaka Yoshizaki ${ }^{e}$ Masashi Tatsumib, d Naokazu Takedab, d Koji Ishii ${ }^{\text {e }}$ \\ ${ }^{a}$ National Institute of Health and ${ }^{b}$ Thailand-Japan Research Collaboration Center on Emerging and Re-Emerging \\ Infections, Department of Medical Sciences, Ministry of Public Health, Nonthaburi, and 'Division of Immunology,

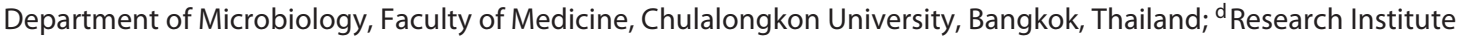

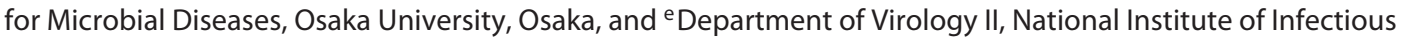 \\ Diseases, Tokyo, Japan
}

\section{Keywords \\ Hepatitis A virus - Drinking water - Phylogenetic analysis . Molecular epidemiology}

\begin{abstract}
Background: In 2000, an outbreak of acute hepatitis A was reported in a province adjacent to Bangkok, Thailand. Aims: To investigate the cause of the 2000 hepatitis A outbreaks in Thailand using molecular epidemiological analysis. Methods: Serum and stool specimens were collected from patients who were clinically diagnosed with acute viral hepatitis. Water samples from drinking water and deep-drilled wells were also collected. These specimens were subjected to polymerase chain reaction (PCR) amplification and sequencing of the $\mathrm{VP} 1 / 2 \mathrm{~A}$ region of the hepatitis $\mathrm{A}$ virus (HAV) genome. The entire genome sequence of one of the fecal specimens was determined and phylogenetically analyzed with those of known HAV sequences. Results and Conclusions: Eleven of $24 \mathrm{fecal}$ specimens collected from acute viral hepatitis patients were positive as determined by seminested reverse transcription PCR targeting the VP1/2A region of HAV. The nucleotide sequence of these samples had
\end{abstract}

an identical genotype IB sequence, suggesting that the same causative agent was present. The complete nucleotide sequence derived from one of the samples indicated that the Thai genotype IB strain should be classified in a unique phylogenetic cluster. The analysis using an adjusted odds ratio showed that the consumption of groundwater was the most likely risk factor associated with the disease.

(C) 2017 S. Karger AG, Basel

\section{Introduction}

Hepatitis A virus (HAV) is a nonenveloped singlestranded positive-sense RNA virus classified into the family Picornaviridae and a causative agent of acute hepatitis A [1]. HAV spread via the fecal-oral route either by ingestion of contaminated food and water or by personto-person contact, and most HAV infections are symptomless [2]. The symptoms of HAV infection are selflimited, generally lasting 1-2 months, and require hospitalization and proper therapy. Host immunity after a single infection gives long-lasting protection against hepatitis A [3]. HAV is generally acquired during virus

\section{KARGER}

E-Mail karger@karger.com

www.karger.com/int
(C) 2017 S. Karger AG, Basel

0300-5526/17/0594-0197\$39.50/0
Koji Ishii, PhD

Department of Virology II

National Institute of Infectious Diseases

4-7-1, Gakuen, Musashimurayama, Tokyo 208-0011 (Japan)

E-Mail kishii@ nih.go.jp 
circulation associated with poor hygiene and sanitary conditions [4].

HAV has a genome approximately $7.5 \mathrm{~kb}$ in length, and it contains a long $5^{\prime}$ untranslated region (UTR), a long open reading frame, and a short $3^{\prime}$ UTR containing a poly (A) tail $[5,6]$. Genomic analysis of HAV strains from various geographic areas has revealed their origin and transmission pattern [7]. Nucleotide sequence analyses followed by phylogenetic analyses have revealed that these strains can be categorized into 6 genotype groups (I-VI) based on HAV isolates from various countries; genotypes I-III are found in humans, and each of these is further divided into 2 subgenotypes, i.e., A and B. Most human HAV strains belong to genotype I or III [8-10].

In Thailand, the monitoring of viral hepatitis has been carried out under a nationwide surveillance system, and suspected cases of hepatitis were reported in the surveillance report published in National Disease Surveillance (Report 506), Bureau of Epidemiology, Department of Disease Control, Ministry of Public Health, Thailand. In 2015 , of these suspected cases, only $4.7 \%(398 / 8,495)$ were diagnosed as hepatitis A [11].

In 2000, eighteen suspected hepatitis cases with fever and jaundice were reported to the authorities in Nakhon Pathom Province, a province adjacent to Bangkok, and most of these cases involved students. An extensive survey by the provincial authority revealed that this outbreak was caused by a drinking water supplier [12].

In the present study, we genetically analyzed specimens from the hepatitis patients, drinking water, and deep-drilled wells owned by the water supply company and found that the outbreak was caused by HAV of genotype IB.

\section{Materials and Methods}

\section{Serum Samples}

Serum specimens were collected in a province near Bangkok, i.e., Nakhon Pathom, Thailand, in July and August of 2000, including samples from patients who were clinically diagnosed with acute viral hepatitis and samples from healthy persons as a control group. The specimens were tested for anti-HAV IgM antibody (VIDAS HAV IgM; BioMérieux, Marcy l'Etoile, France), anti-HAV total antibody (VIDAS anti HAV total; BioMérieux), anti-HBc IgM antibody (VIDAS HBc IgM; BioMérieux), anti-HCV IgG antibody (ETI-AB-HCVK-4; DiaSorin, Saluggia, Italy), and anti-HEV IgM antibody (HEV-IgM ELISA; MP Diagnostic, Singapore).

\section{Stool Samples}

One-gram fecal specimens were collected from the acute viral hepatitis patients. The samples were diluted with phosphate-buffered saline ( $\mathrm{pH} 7.4)$ to prepare a $10 \%(\mathrm{w} / \mathrm{v})$ suspension.

\section{Water Samples}

One-liter water samples were collected, dechlorinated with sodium thiosulfate (Sigma Chemical Co., St. Louis, MO, USA) at a final concentration of $50 \mathrm{mg} / \mathrm{L}$, and stored at $4^{\circ} \mathrm{C}$. HAV was concentrated by adding $\mathrm{AlCl}_{3} \cdot 6 \mathrm{H}_{2} \mathrm{O}$ at a final concentration of 120 $\mathrm{mg} / \mathrm{L}$ of the water sample, and adjusted to $\mathrm{pH} 3.5$ with $1.0 \mathrm{~N} \mathrm{HCl}$. The samples were filtered through a $0.22-\mu \mathrm{m}$ filter (Millipore, Bedford, MA, USA). The filter was washed 5 times with $1 \mathrm{~mL}$ of 0.14 $\mathrm{N} \mathrm{NaCl}$ to remove excess $\mathrm{Al}^{+}$. The virus was eluted 3 times with $3 \mathrm{~mL}$ of $3 \%$ beef extracts ( $\mathrm{pH} 9.0$ ), and then $300 \mu \mathrm{L}$ of antibiotics (10,000 units/mL of penicillin and $10,000 \mu \mathrm{g} / \mathrm{mL}$ of streptomycin) and $300 \mu \mathrm{L}$ of $10 \times$ MEM were added to the eluent. The sample was kept at $-70^{\circ} \mathrm{C}$ until further processing. One milliliter (1,440 ELISA units of the HM-175 strain) of the hepatitis A vaccine (1,440 ELISA units, Havrix ${ }^{\mathrm{TM}}$; GSK Vaccines) was included to estimate the virus recovery. All samples were tested in triplicate.

\section{Statistical Analysis}

STATA software (version 6.0) was used to calculate the odds ratio $(\mathrm{OR})$ and $95 \%$ confidence interval $(95 \% \mathrm{CI})$ between the risk factors and the disease.

\section{RNA Extraction and Reverse Transcription Polymerase Chain}

\section{Reaction}

Viral RNA was extracted from $100 \mu \mathrm{L}$ of the concentrated water samples and $10 \%$ stool suspensions using the Trizol reagent (Life Technologies, Rockville, MD, USA) according to the manufacturer's instructions. The reverse transcription of viral RNA was performed as described previously [13]. Degenerated primers, i.e., HAV-JCT-2F, HAV-JCT-1R-A, and HAV-JCT-2R, were used to amplify via polymerase chain reaction (PCR) the $\mathrm{VP} 1 / 2 \mathrm{~A}$ region of the HAV genome. The HAV-JCT-2F and HAV-JCT-1R-A primers were used for the initial PCR amplification of the HAV sequences, and the HAV-JCT-2F and HAV-JCT-2R primers were used for a second round of semi-nested PCR. All PCR conditions have been described previously [14].

\section{Entire Genome Sequencing}

In order to determine nearly complete sequences of the Thai IB HAV strain, the whole genome was divided into 7 regions, each region was amplified by reverse transcription PCR (RT-PCR), and direct sequencing was performed as described $[13,14]$. The PCR primers used for amplification and sequencing are shown in Table 1.

\section{Phylogenetic Analysis}

CLUSTAL W version 1.4 [15] was used to align the HAV nucleotide sequences. The 2-parameter method of Kimura [16] was then used to generate a distance matrix of nucleotide substitutions per site from the sequence alignments. MEGA version 4.0 was used to generate neighbor-joining trees [17], maximum-likelihood trees, and unweighted pair group method with arithmetic averages (UPGMA) trees from the matrix numbers; each tree was constructed with 100 bootstrap replicates [18]. All reference sequences used in this study were obtained from GenBank.

Nucleotide Sequence Accession Numbers

The GenBank accession number of the nearly complete nucleotide sequences determined in this study is LC128713. The accession numbers of the other strains used in this study are: genotype 
Table 1. Primers used to determine the entire nucleotide sequence

\begin{tabular}{lll}
\hline Primer & Sequence $\left(5^{\prime} \rightarrow 3^{\prime}\right)$ & Position \\
\hline $1 \mathrm{~F}$ & TTC AAG AGG GGT CTC CGG & $1-18$ \\
$153 \mathrm{R}$ & GAA CCC TGA ACC TGC AGG A & $153-135$ \\
$32 \mathrm{~F}$ & CCC TCT TGG AAG TCC ATG GTG A & $32-54$ \\
$516 \mathrm{R}$ & ACT CAA TGC ATC CAC TGG ATG AG & $516-494$ \\
$992 \mathrm{~F}$ & ATT CAT TCT GCA GAT TGG CTT & $992-1012$ \\
$1233 \mathrm{R}$ & CAA TTC AAC AAA CCA TGA GGA TA & $1233-1211$ \\
$1549 \mathrm{~F}$ & AGG AAG ATT GGA AAT CTG ATC & $1549-1569$ \\
$1695 \mathrm{R}$ & CYA CTG GAA TAA CTT TAA TTT & $1695-1675$ \\
$1977 \mathrm{~F}$ & AGA TTT CGT GTG CCC TGG ATT TC & $1977-1999$ \\
$2275 \mathrm{R}$ & CAT GGT TGT ACC AAC TTG & $2275-2256$ \\
$3162 \mathrm{R}$ & CTT CYT GAG CAT ACT TKA RTC TTT G & $3162-3138$ \\
$2907 \mathrm{~F}$ & GCA AAT TAC AAT CAT TCT GAT GA & $2907-2929$ \\
$4392 \mathrm{R}$ & GTY CAT TCA ATG GCW CAR GTT GA & $4392-4368$ \\
$4290 \mathrm{~F}$ & ATA ACA AAC TGG TTC ACA TCT & $4290-4313$ \\
$5520 \mathrm{R}$ & TTD GGA ATT GTA GGM ACC TTC AT & $5520-5498$ \\
$5383 \mathrm{~F}$ & TGT GAG ATG GGT TAT GAA TGC & $5383-5403$ \\
$6609 \mathrm{R}$ & CRT CCC ACT GTC ATC WGG A & $6609-6591$ \\
$6518 \mathrm{~F}$ & TTA TAC AAT TTT GTG TAG AAT GTA & $6518-6541$ \\
$7435 \mathrm{R}$ & ACA AAC CTC AGA AAT TTT AAG AA & $7435-7413$ \\
$3451 \mathrm{R}(\mathrm{JCT}-1 \mathrm{R}-\mathrm{A})$ & YTT RTC ATC YTT CAT TTC TGT CCA & $3451-3427$ \\
$2784 \mathrm{~F}(J C T-2 \mathrm{~F})$ & GRA GAA CAG GRA AYA TTC ARA TTA G & $2784-2809$ \\
$3376 \mathrm{R}(\mathrm{JCT}-2 \mathrm{R})$ & CAG THA RMA CHC CAG CAT CCA T & $3376-3398$ \\
\hline
\end{tabular}

The positions of the primers were numbered according to the complete nucleotide sequence of the HM 175 strain (accession No. M14707).

IA (K02990, X83302, X75215, AB969748, AB839692, AF485328, AB020569, AF512536, AF357222, AB020564, EU131373, and KJ427799), genotype IB (HQ246217, M20273, EF406359, AF314208, M14707, KF724023, and AF268396), genotype II (AY644676 and AY644670), genotype IIIA (AB279733, FJ360735, EU011791, JQ655151, AB973400, and AJ299464), and genotype IIIB (AB258387, AB300205, and AB279735). In addition, the following genotype IB strains were used to compare the VP1/2A (286 bases) region (AB258562, AB974364, AF050229, AF050231, AF268396, AF314208, AY741663, DQ452807, EU930199, FJ010834, GU646039, HQ246217, HQ907924, KC632110, KC876797, KC876799, KF724023, KP091364, KP091376, KT222956, LC035019, LC037391, M14707, and M20273).

\section{Results}

\section{Outbreaks of Hepatitis in 2000}

An outbreak of hepatitis occurred from July to August of 2000 in Nakhon Pathom Province, next to metropolitan Bangkok. During this outbreak, a total of 18 hepatitis patients who had jaundice with fever or fever with enteric abnormality were observed. A case-control study was performed to find any association between risk fac- tors and the disease. From 18 cases and 48 controls, a relation was established between 2 kinds of food consumption, i.e., noodles (crude OR 5.76; 95\% CI 1.61-20.56) and water/ice (crude OR 6.11; 95\% CI 1.26-29.64), and the disease. In addition, a relation between the consumption of groundwater (crude OR 5.18; 95\% CI 1.53-17.53) and the disease was observed. From the analysis using adjusted OR with these 3 risk factors, the consumption of groundwater was the most likely risk factor associated with the disease (crude adjusted OR 3.76; 95\% CI 1.0420.15) [12].

\section{Genetic Analysis of Thai HAV Isolates in the}

\section{Outbreak}

The 22 serum and 24 fecal specimens collected from the patients were subjected to serological and genetic analyses as described in Materials and Methods. All of the serum samples were negative for anti-HBc IgM, antiHCV IgG, and anti-HEV IgM but positive for anti-HAV IgM (data not shown); however, we were not able to perform further genetic analyses due to the extremely small size of the samples. Eleven of the 24 fecal samples were 
Fig. 1. Phylogenetic tree of HAV based on the complete nucleotide sequence. Bootstrap values are shown at corresponding nodes.

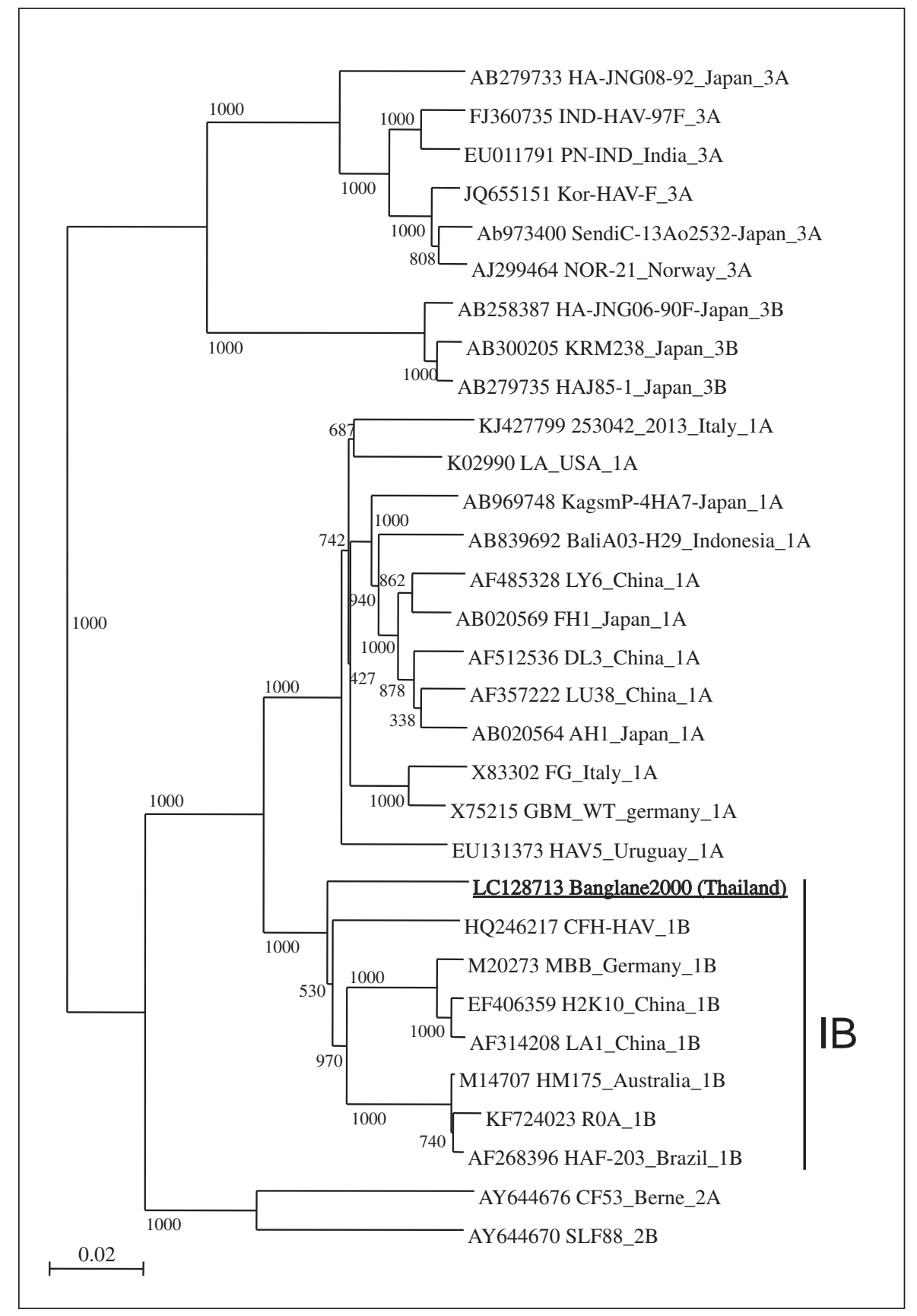

found to be positive by semi-nested RT-PCR targeting the $\mathrm{VP} 1 / 2 \mathrm{~A}$ region of HAV. The nucleotide sequences of PCR products (286 bp) were identical (accession No. AF543485), suggesting that the same causative agent was present [19]. Three of 27 water samples were found to be positive by RT-PCR targeting a short VP1/2A region (data not shown); however, sufficient PCR products for further analysis were not obtained by the seminested RTPCR.
One of the fecal samples was selected to determine the complete nucleotide sequence. Nearly the entire viral genome was amplified as described in Materials and Methods, and the nucleotide sequence was determined using the primers depicted in Table 1. Thus, the Thai hepatitis A IB sequence, which was composed of 7,419 nucleotides, encoded a polyprotein composed of 2,225 amino acids and was submitted to the National Center for Biotechnology Information (NCBI) database (accession No. 
Fig. 2. Phylogenetic tree of genotype IB HAV based on a 286-nucleotide fragment of the $\mathrm{VP} 1 / 2 \mathrm{~A}$ region. Bootstrap values are shown at corresponding nodes.

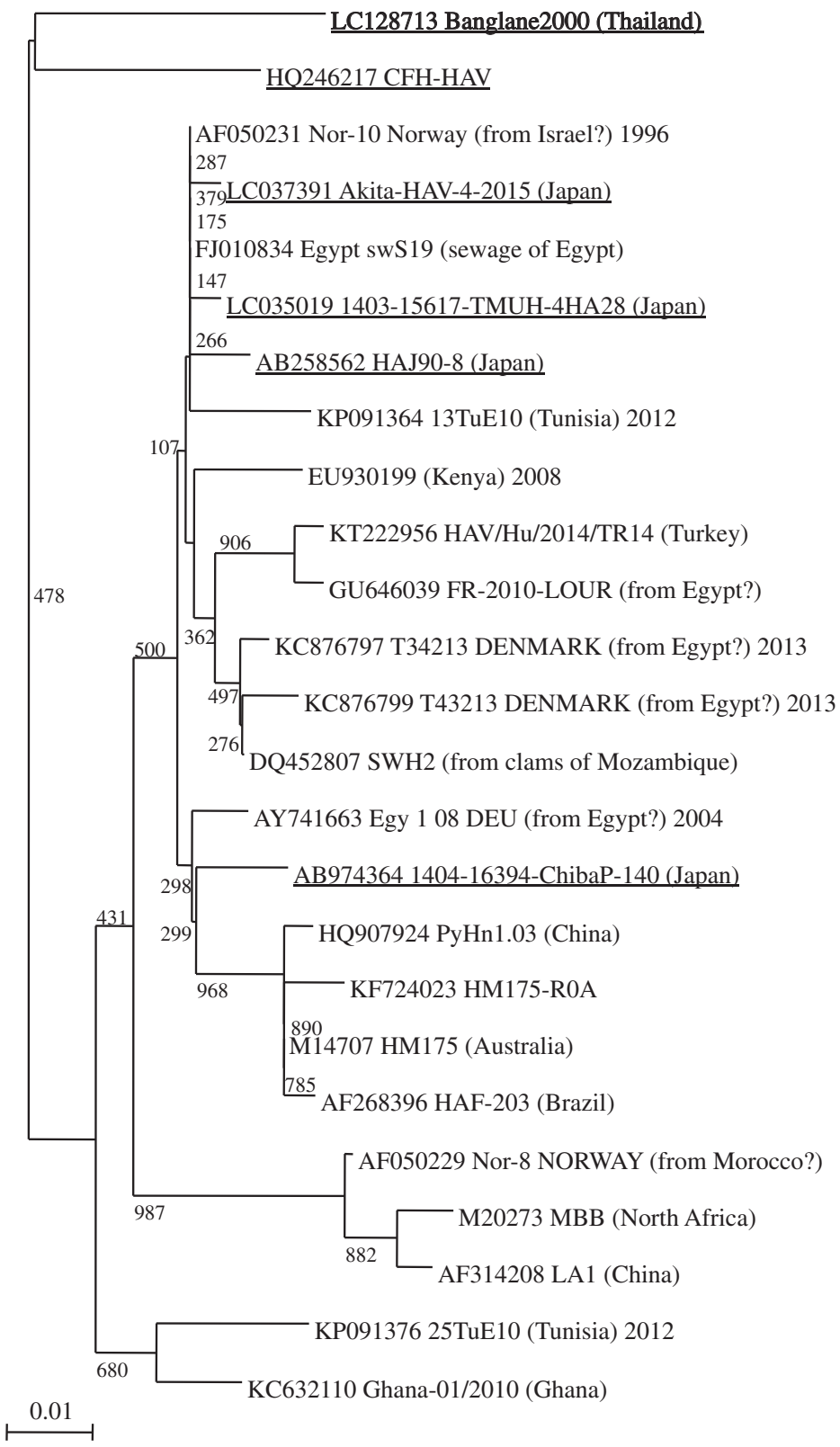

LC128713, Banglane2000). The sequence showed a base composition of 2,176 A (29.3\%), 1,201 C (16.2\%), $1617 \mathrm{G}$ (21.8\%), and 2,418 T (32.6\%).

The nucleotide identity of the Banglane2000 strain with other genotype IB strains deposited in GenBank (HQ246217, M20273, EF406359, AF314208, M14707, KF724023, and AF268396) ranged from 93.7 to $94.5 \%$, whereas the amino acid sequences showed little difference, displaying identities of 98.0-99.4\%. Banglane2000 showed $94.5 \%$ nucleotide and $99.4 \%$ amino acid identities with the vaccine strain HM175, and 94.0\% nucleotide and $99.2 \%$ amino acid identities with the CFH-HAV strain, which was isolated from a male chimpanzee infected with HAV [20]. Phylogenetic analysis of the whole sequences in comparison to those of known HAV sequences indicated that the Thai IB strain is likely to be grouped into a unique cluster (Fig. 1). 
When the amino acid sequence of the whole coding region was compared with those of 7 known HAV IB strains, we found the following 12 amino acid differences: R67K, C796S, V1052A, K1168R, E1341G, I1424V, K1488R, K1554R, V1818I, V1888I, P1910S, and S1930I, with which the Banglane2000 strain shared 13 mutations, i.e., R67K, C796S, E1151K, K1168R, E1341G, I1424V, K1488R, K1554R, Y1764H, V1888I, V1818I, P1910S, and S1930I, with the vaccine strain HM175.

\section{Discussion}

Recently, improvements in hygiene and sanitary conditions and the application of public health control measures have led to a significant shift in the epidemiology of hepatitis A from high to intermediate to low endemicity in Thailand [21]. This shift has resulted in a growing population of susceptible adolescents and adults, the groups most likely to be symptomatic when infected with HAV, and may lead to outbreaks of the disease.

Most HAV strains isolated in Thailand have been reported to be genotype IA [19, 22-24], whereas genotype IB HAV is predominant in the Middle East. Several recent outbreaks of acute hepatitis A caused by genotype IB were associated with food from Middle Eastern countries such as frozen strawberries from Egypt and Morocco in Europe [25], frozen pomegranate seeds from Egypt in Canada in 2012 [26], semidried tomatoes from Turkey in Europe $[27,28]$ and Australia [29] in 2009-2011, and frozen pomegranate arils from Turkey in the USA [30]. Our molecular epidemiological study using a 286-nucleotide fragment of the VP1/2A region revealed that Banglane2000 belongs to a cluster distinct from other IB strains except for the CFH-HAV strain (HQ246217) (Fig. 2). CFH-HAV, which shares $94.0 \%$ nucleotide homology with Banglane2000, was isolated from a chimpanzee that was imported from Sierra Leone to Japan in 1980 and developed fulminant hepatitis A about 3 months after arrival [20]. Considering the incubation period of hepatitis A ( 1 month), this chimpanzee was considered to have been infected with HAV in Japan. However, almost all genotype IB cases reported in Japan were imported cases (underlined strains in Fig. 2); therefore, no information concerning Japanese domestic IB is available. Whether Banglane2000 is a domestic strain in Thailand or not remains an open question. This is the first report of the fulllength sequence of an HAV isolated in Thailand. The sequence will be useful for comparison with the full-length HAV sequences of the other strains isolated throughout the world in the future.

\section{Acknowledgements}

This research was partially supported by the Japan Initiative for Global Research Network on Infectious Diseases (J-GRID) of the Ministry of Education, Culture, Sport, Science, and Technology of Japan, and by the Research Program on Hepatitis of the Japan Agency for Medical Research and Development (AMED). This study was also supported by the Department of Medical Sciences, Ministry of Public Health, Thailand.

\section{Disclosure Statement}

The authors declare that they have no competing interests of either a financial or a nonfinancial nature regarding the work described in the present paper.

\section{References}

1 Van Regenmortel MH: Viruses are real, virus species are man-made, taxonomic constructions. Arch Virol 2003;148:2481-2488.

2 Morse LJ, Bryan JA, Hurley JP, Murphy JF, O'Brien TF, Wacker WE: The Holy Cross college football team hepatitis outbreak. JAMA 1972;219:706-708.

3 Schiff ER: Atypical clinical manifestations of hepatitis A. Vaccine 1992;10(suppl 1):S18S20.

4 Bell BP: Global epidemiology of hepatitis A: implications for control strategies; in Margolis HS, Alter MJ, Liang JT, et al (eds): Viral Hepatitis and Liver Disease. London, International Medical Press, 2002.
5 Najarian R, Caput D, Gee W, Potter SJ, Renard A, Merryweather J, Van Nest G, Dina D: Primary structure and gene organization of human hepatitis A virus. Proc Natl Acad Sci USA 1985;82:2627-2631.

6 Cohen JI, Ticehurst JR, Purcell RH, BucklerWhite A, Baroudy BM: Complete nucleotide sequence of wild-type hepatitis A virus: comparison with different strains of hepatitis A virus and other picornaviruses. J Virol 1987; 61:50-59.

7 Robertson BH, Khanna B, Nainan OV, Margolis HS: Epidemiologic patterns of wild-type hepatitis A virus determined by genetic variation. J Infect Dis 1991;163:286-292.
8 Robertson BH, Jansen RW, Khanna B, Totsuka A, Nainan OV, Siegl G, Widell A, Margolis HS, Isomura S, Ito K, Ishizu T, Moritsugu Y, Lemon AM: Genetic relatedness of hepatitis A virus strains recovered from different geographical regions. J Gen Virol 1992; 73:1365-1377.

9 Lu L, Ching KZ, de Paula VS, Nakano T, Siegl G, Weitz M, Robertson BH: Characterization of the complete genomic sequence of genotype II hepatitis A virus (CF53/Berne isolate). J Gen Virol 2004;85:2943-2952.

10 Hollinger FB, Emerson SU: Hepatitis A virus; in Knipe DM, Howley PM (eds): Fields Virology. Philadelphia, Lippincott Williams and Wilkins, 2001 pp 799-840. 
11 Bureau of Edpidemiology of Thailand: Number of cases and deaths by month and province. http://www.boe.moph.go.th/boedb/surdata/disease.php?dcontent $=$ old \&ds $=111$.

12 Utaipiboon C, Namwat C, Kijphati R, Wattanasri N, Ruchusatsawat K, Tharmaphornpilas P: Outbreak of hepatitis A from contamination of water supply (in Thai). J Health Sci 2002;11:452-459.

13 Ishii K, Kiyohara T, Yoshizaki S, Wakita T, Shimada T, Nakamura N, Tada Y, Noda M: Epidemiological and genetic analyses of a diffuse outbreak of hepatitis A in Japan, 2010. J Clin Virol 2012;53:219-224.

14 Ishii K, Kiyohara T, Yoshizaki S, Kawabata K, Kanayama A, Yahata Y, Takahashi T, Kinoshita H, Saitou T, Sunagawa T, Oishi K, Uema M, Noda M, Wakita T: Epidemiological and genetic analysis of a 2014 outbreak of hepatitis A in Japan. Vaccine 2015;33:60296036.

15 Thompson JD, Higgins DG, Gibson TJ: CLUSTAL W: improving the sensitivity of progressive multiple sequence alignment through sequence weighting, position-specific gap penalties and weight matrix choice. $\mathrm{Nu}$ cleic Acids Res 1994;22:4673-4680.

16 Kimura M: A simple method for estimating evolutionary rates of base substitutions through comparative studies of nucleotide sequences. J Mol Evol 1980;16:111-120.

17 Saitou N, Nei M: The neighbor-joining method: a new method for reconstructing phylogenetic trees. Mol Biol Evol 1987;4:406-425.

18 Tamura K, Dudley J, Nei M, Kumar S: MEGA4: Molecular Evolutionary Genetics Analysis (MEGA) software version 4.0. Mol Biol Evol 2007;24:1596-1599.
19 Wattanasri N, Ruchusatsawat K, Wattanasri S: Phylogenetic analysis of hepatitis A virus in Thailand. J Med Virol 2005;75:1-7.

20 Theamboonlers A, Abe K, Thongmee C, Poovorawan Y: Complete coding sequence and molecular analysis of hepatitis A virus from a chimpanzee with fulminant hepatitis. J Med Primatol 2012;41:11-17.

21 Chatpoedprai S, Chongsrisawat V, Chatchatee $\mathrm{P}$, Theamvoonlers A, Yoocharoen $\mathrm{P}$, Tharmaphornpilas $\mathrm{P}$ Warinsathien $\mathrm{P}$, Tharmaphornpilas P, Warintrawat S, Sinlaparatsamee S, Chaiear K, Khwanjaipanich S, Paupunwatana S, Poovorawan Y: Declining trend in the seroprevalence of infection with hepatitis A virus in Thailand. Ann Trop Med Parasitol 2007;101:61-68.

22 Theamboonlers A, Jantaradsamee P, Chatchatee $\mathrm{P}$, Chongsrisawat V, Mokmula M, Poovorawan Y: Molecular characterization of hepatitis-A-virus infections, in the context of two outbreaks in southern Thailand. Ann Trop Med Parasitol 2002;96:727-734.

23 Barameechai K, Sa-Nguanmoo P, Suwannakarn K, Thongmee C, Payungporn S, Chongsrisawat V, Theamboonlers A, Poovorawan Y: Molecular characterization of the hepatitis A virus circulating in the 2001-2005 outbreaks in Thailand. Ann Trop Med Parasitol 2008; 102:247-257.

24 Theamboonlers A, Rianthavorn P, Jiamsiri S, Kumthong S, Silaporn P, Thongmee C, Poovorawan Y: Molecular characterization of Hepatitis A virus causing an outbreak among Thai navy recruits. Trop Biomed 2009;26: 352-359.

25 Nordic Outbreak Investigation Team C: Joint analysis by the Nordic countries of a hepatitis A outbreak, October 2012 to June 2013: frozen strawberries suspected. Euro Surveill 2013;18:20520.
26 Swinkels HM, Kuo M, Embree G; Fraser Health Environmental Health Investigation Team, Andonov A, Henry B, Buxton JA: Hepatitis A outbreak in British Columbia, Canada: the roles of established surveillance, consumer loyalty cards and collaboration, February to May 2012. Euro Surveill 2014;19:20792.

27 Petrignani M, Harms M, Verhoef L, van Hunen R, Swaan C, van Steenbergen J, Boxman I, Peran I Sala R, Ober H, Vennema H, Koopmans M, van Pelt W: Update: a foodborne outbreak of hepatitis A in the Netherlands related to semi-dried tomatoes in oil, January-February 2010. Euro Surveill 2010; 15:19572.

28 Gallot C, Grout L, Roque-Afonso AM, Couturier E, Carrillo-Santisteve P, Pouey J, Letort MJ, Hoppe S, Capdepon P, Saint-Martin S, De Valk H, Vaillant V: Hepatitis A associated with semidried tomatoes, France, 2010. Emerg Infect Dis 2011;17:566-567.

29 Donnan EJ, Fielding JE, Gregory JE, Lalor K, Rowe S, Goldsmith P, Antoniou M, Fullerton KE, Knope K, Copland JG, Bowden DS, Tracy SL, Hogg GG, Tan A, Adamopoulos J, Gaston J, Vally H: A multistate outbreak of hepatitis A associated with semidried tomatoes in Australia, 2009. Clin Infect Dis 2012;54:775-781.

30 Collier MG, Khudyakov YE, Selvage D, Adams-Cameron M, Epson E, Cronquist A, Jervis $\mathrm{RH}$, Lamba $\mathrm{K}$, Kimura AC, Sowadsky R, Hassan R, Park SY, Garza E, Elliott AJ, Rotstein DS, Beal J, Kuntz T, Lance SE, Dreisch R, Wise ME, Nelson NP, Suryaprasad A, Drobeniuc J, Holmberg SD, Xu F; Hepatitis A Outbreak Investigation Team: Outbreak of hepatitis A in the USA associated with frozen pomegranate arils imported from Turkey: an epidemiological case study. Lancet Infect Dis 2014;14:976-981. 